\title{
EARLY CHILDHOOD LEARNING
}

\author{
Saidna Zulfiqar bin Tahir \\ Unieversitas Iqra Buru, Maluku \\ saidnazulfiqar@gmail.com
}

\begin{abstract}
All children in this world, from any circle they come from, must like to play. Playing is an activity that is unique and very different from other activities such as work, which adults always do to achieve a final result. Therefore, this article will discuss the knowledge of learning and learning theory for early childhood, which is beneficial not only for teachers in PAUD institutions but also for parents and other adults responsible for teaching their children wherever and whenever.
\end{abstract}

Keywords: Childhood, learning

\section{INTRODUCTION}

When children learn how to use computers, they may make mistakes in the learning process, but at some point, they will become accustomed to taking the actions needed to use the computer effectively. Children will change from someone who cannot operate a computer to someone who can manage it. So, learning can be defined as an enduring influence on behavior, knowledge, and thinking skills acquired through experience. Not everything we know is obtained by learning. We inherit some of these abilities from birth, not learned. For example, we do not have to be taught to swallow food, scream or blink during glare. The scope of learning is broad (Domjan, 2018). Learning involves academic and non-academic behavior. Learning takes place at school or anywhere in the world of children.

\section{Approaches in Learning}

Behaviorism is the view that behavior must be explained through visual experiences, not by mental processes. According to behaviorists, behavior is anything that we can do and can see directly: children make posters, teachers smile at children, disturb other students, etc. Mental processes are defined by psychologists as feelings, thoughts, and motives that we experience but are not seen directly by others.

Cognitive Psychology increasingly tended to take a cognitive viewpoint during the last decades of the 20th century, and this cognitive emphasis has continued to the present day. This cognitive suppression has continued today. Cognitive emphasis forms the basis for many approaches to learning. The social cognitive approach emphasizes how behavioral, environmental, and people (cognitive) factors that interact with each other affect the learning process. The second approach, information processing, focuses on how children process information through attention, memory, thinking, and other 
cognitive functions. The third approach, cognitive constructivist, emphasizes cognitive constructs of knowledge and understanding. The fourth approach, the social constructivist, focuses on collaborating with others to generate knowledge and experience. The social constructivist approach was initially introduced in the form of the Vygotsky theory.

By adding these four cognitive approaches to the behavioral process, we arrive at the five main approaches to learning we are discussing: behavioral, social cognitive, cognitive information processing, cognitive constructivist, and social constructivist. All of them support our understanding of how children learn.

\section{Early Childhood Learning Theory}

You need to know that learning is an individual process, which changes the simulation. There is an information process that results in learning outcomes in memory and changes in behavior. In early childhood education, this is the primary learning for children, where knowledge can form long-term memory and influence children's behavior. For this reason, there is a learning theory in early childhood that includes several aspects, namely:

a. Behavior changes that can be observed by the way children think

b. Learning theory collects integrated principles and regulates learning situations or environments to achieve learning goals quickly.

c. The learning theory is that there is an interaction between teachers and students with their environment, which causes better behavior changes and potential in children.

\section{A BEHAVIORAL APPROACH TO LEARNING}

Classical Conditioning is a type of learning in which an organism learns to associate or associate stimuli. In classical Conditioning, a neutral stimulus (such as looking at someone) is associated with a meaningful stimulus (such as food). It gives rise to the capacity to produce the same response. To understand Pavlov's (1972) classical conditioning theory, we must understand two types of stimuli and two types of response: unconditioned stimulus (US), unconditioned response (UR), the conditioned stimulus (CS) and conditional response (CR). Unconditioned response (UR) is an unlearned response that we automatically generate. Conditioned response (CR) is studied, namely, the response to a conditioned stimulus that appears after the US-CS pair occurs.

Generalization, Discrimination, and Annihilation. The generalization in classical Conditioning is the tendency in the same new stimulus as the original conditioned stimulus to produce the same response. Suppose the student is scolded for a bad biological exam. Discrimination in classical Conditioning occurs when organisms respond to certain stimuli but do not respond to other stimuli. Extinction in classical 
Conditioning is a weakening of the conditioned response (CR) due to the absence of an unconditioned stimulus (US).

Systematic Desensitization. (Systematic desensitization) is a method based on classical Conditioning intended to reduce anxiety by making the individual associate relaxation with the visualization of anxious situations.

They are evaluating Classical Conditioning. Classical Conditioning helps us understand some aspects of learning well. This method helps explain how neutral stimuli become associated with unlearned and voluntary responses (LoLordo, 2000). This is very helpful in understanding the student's anxiety and fear. However, this method is not effective at explaining voluntary behavior, such as why students study hard for one subject or prefer history to geography. For this area, operant conditioning will be more relevant.

Operant Conditioning. Also called instrumental Conditioning is a form of learning in which the consequences of behavior result in a change in the probability that the behavior will be repeated.

Thorndike Effect Law. Thorndike's (law effect) states that behavior followed by positive results will be strengthened and that behavior followed by negative consequences will be weakened.

Skinner's Operant Conditioning Operant conditioning, in which the consequences of behavior will cause a change in the probability that the behavior will occur, is at the heart of Skinner's (1938) behaviorism. Consequences-rewards or punishments-are temporary (contingent) on the behavior of the organism.

Confirmation and Punishment. Reinforcement is a consequence that increases the probability that a behavior will occur. Conversely, punishment (punishment) is a consequence that reduces the probability of a behavior occurring. For example, you might say to your student, "Congratulations. I feel happy after reading the stories you wrote"

Generalization, discrimination, and elimination. Generalization in operant Conditioning means giving the same response to the same stimuli. What is interesting is the extent to which behavior is generalized from situation to situation. For example, if the teacher's praise made students study harder in class, would similar praise also make students work harder on assignments outside the classroom, such as homework? Discrimination in operant Conditioning means differentiation between the incident and environmental stimuli. For example, a student knows that the drawer on the teacher's desk that says "math" is where the teacher keeps today's math assignments, while the one that speaks "English" is the place to store today's English lessons. In operant Conditioning, extinction occurs when the previous amplifier response is no longer amplified, and the response decreases. In class, the most common use of exclusion for teachers is to stop paying attention to behavior. For example, in some cases, the teacher 
pays unwise attention to reinforce the disruptive action, such as when a student pinches another student and the teacher then immediately talks to the perpetrator.

Early childhood learning models have two types of teacher-centered learning models and child-centered learning. Teacher-centered learning was initiated by Povdov, Skinner, and other behaviorists. Piaget, Erikson, and Isaacs began child-centered learning.

Behaviorist theory, based on Pavlov's research in observing animal behavior, states that if an animal is given certain stimulation, it causes a specific response according to the stimulation provided. Skinner argues that all human behavior can be explained or observed as a response formed from various stimuli that have been received from the environment.

Developmental Theory, developmental psychologists, see that children have the self-motivation they are born with to become capable. This "motivated ability" is then seen by psychologists as the basis for developing child-centered learning by appreciating the child's entire developmental process and developing according to the rhythm of each child by creating an environment and providing the appropriate tools. Provide opportunities for children to learn and develop.

Psychologists have found patterns and stages in development that come from the control that arises from within children, such as cognitive, socio-emotional, and physical development. Through this knowledge, a play-based learning environment can be created for children to support children's development.

\section{CLOSING}

All children in this world, from any circle they come from, must like to play. Playing is an activity that is unique and very different from other activities such as work, which adults always do to achieve a final result. Therefore, knowledge of learning and learning theory for early childhood is beneficial not only for teachers at PAUD institutions but also for parents and other adults responsible for teaching their children wherever and whenever.

\section{REFERENCES}

Amrin, A., Cahaya, A., Yusriadi, Y., \& Sakkir, G. (2020, February). Level of Elderly Depression in Palopo City. In Proceeding of International Conference on Engineering, Technology, and Social Sciences (ICONETOS) (Vol. 1, No. 1, pp. 48-50).

Atmowardoyo, H., Weda, S., \& Sakkir, G. (2020). Information Technology used by Millennial Good English Language Learners in an Indonesian University to Improve their English Skills. Solid State Technology, 63(5), 9532-9547.

Bereiter, C. (1990). Aspects of an educational learning theory. Review of educational research, 60(4), 603-624.

Bin Tahir, S. Z. (2015). Multilingual behavior of Pesantren IMMIM students in Makassar. Asian EFL Journal, 86, 45-64.

Bin-Tahir, S. Z., Atmowardoyo, H., Dollah, S., \& Rinantanti, Y. (2017). Multilingual learning program: pesantren students' perceptions of the multilingual simultaneous-sequential model. JELE (Journal Of English Language and Education), 3(2), 44-53. 
Bin-Tahir, S. Z., Suriaman, A., \& Rinantanti, Y. (2019). Designing English Syllabus for Multilingual Students at Pesantren Schools. Asian EFL Journal, 23(3.3), 5-27.

Bin-Tahir, S. Z., Hanapi Hanapi, I. H., \& Suriaman, A. (2020). Avoiding Maluku Local Languages Death Through Embedded Multilingual Learning Model: Menghindari Kematian Bahasa Daerah Maluku melalui Model Pembelajaran Embedded Multilingual. Uniqbu Journal of Social Sciences, 1(1), 5360.

Dollah, S., Sakkir, G., \& Sunra, L. (2020, November). Pelatihan Tour Guide bagi Pemuda Karang Taruna. In Seminar Nasional Pengabdian Kepada Masyarakat.

Domjan, M., Cusato, B., \& Villarreal, R. (2000). Pavlovian feed-forward mechanisms in the control of social behavior. Behavioral and Brain Sciences, 23(2), 235-248.

Domjan, M., Cusato, B., \& Villarreal, R. (2000). Pavlovian feed-forward mechanisms in the control of social behavior. Behavioral and Brain Sciences, 23(2), 235-248.

Kasmawati, K., \& Sakkir, G. (2020). IMPROVING STUDENTS READING COMPREHENSION THROUGH "SURVEY, QUESTION, READING, RECITE, REVIEW (SQ3R)" STRATEGY. Interference: Journal of Language, Literature, and Linguistics, 1(2), 92-99.

Latif, A., Mustanir, A., Ahmad, J., \& Sakkir, G. (2019, November). Village Government Leadership Towards Optimizing Society Participation in Development Planning. In International Conference on Democratisation in Southeast Asia (ICDeSA 2019) (pp. 12-16). Atlantis Press.

Mowrer, O. (1960). Learning theory and behavior.

Rahman, H., Sakkir, G., \& Khalik, S. (2020). Audio-Lingual Method to Improve Students's Speaking Skill at Smp Negeri 1 Baranti. La Ogi: English Language Journal, 6(1), 15-21.

Sakkir, G. (2018). Pengembangan modul pengajaran menulis berbasis Facebook (Doctoral dissertation, Pascasarjana).

Sakkir, G. (2018). Writing: Beginner. Deepublish.

Sakkir, G. (2020). The Effectiveness of Pictures In Enhance Writing Skill of Senior High School Students. Interference: Journal of Language, Literature, and Linguistics, 1(1).

Sakkir, G., \& Abrar, A. E. Y. (2018, November). Students' perception of the implementation Facebook group in learning writing skill. In Proceedings of the 65th Teflin International Conference (Vol. 65, No. 02).

Sakkir, G., \& Dollah, S. (2019). FACEBOOK-BASED WRITING INSTRUCTIONAL MATERIAL IN ENGLISH CLASS: LECTURERS'PERCEPTION. Seltics, 2(2), 76-83.

Sakkir, G., \& Dollah, S. (2019). Measuring students' writing skills using Facebook group application in EFL context. International Journal of Humanities and Innovation (IJHI), 2(3), 69-74.

Sakkir, G., Dollah, S., \& Ahmad, J. (2020). Favorite E-Learning Media in Pandemic Covid-19 Era. Jurnal Studi Guru dan Pembelajaran, 3(3), 480-485.

Sakkir, G., Dollah, S., \& Ahmad, J. (2020). Students' Perceptions toward Using YouTube in EFL Classrooms. Journal of Applied Science, Engineering, Technology, and Education, 2(1), 1-10.

Sakkir, G., Rahman, Q., \& Salija, K. (2016). Students' Perception on Social Media in Writing Class at STKIP Muhammadiyah Rappang, Indonesia. International Journal of English Linguistics, 6(3), $170-175$.

Syatriana, E., \& Sakkir, G. (2020). Implementing Learning Model Based on Interactive Learning Community for EFL Students of Muhammadiyah University. ELT Worldwide: Journal of English Language Teaching, 7(1), 24-30.

Umar, A., Madani, M., Farida, U., Yusriadi, Y., Tamsa, H., Yahya, M., ... \& Misnawati, M. (2019). OneStop Service Policy as a Bureaucratic Reform in Indonesia. Academy of Strategic Management Journal, 18(2), 1-12.

Yusriadi, Y., Bin-Tahir, S. Z., Farida, U., Sakkir, G., \& Akbar, Z. (2019). Community Perception in the Use of" Songkok Recca" Hats based on Social Stratification. Anthropos: Jurnal Antropologi Sosial dan Budaya (Journal of Social and Cultural Anthropology), 5(1), 31-39. 